\title{
The synergetic modulation of the excitability of central gray matter by a neuropeptide: two protocols using excitation waves in chick retina
}

\author{
VERA M.F. DE LIMA ${ }^{1}$, JOSÉ R.C. PIQUEIRA ${ }^{2}$ and WOLFGANG HANKE ${ }^{3}$ \\ ${ }^{1}$ Departamento de Medicina, Universidade Federal de São João del Rei, Campus de Divinópolis \\ Rua Sebastião Gonçalves Coelho, 400, 35501-296 Divinópolis, MG, Brasil \\ ${ }^{2}$ Departamento de Engenharia de Telecomunicações e Controle, Escola Politécnica, Universidade de São Paulo \\ Avenida Prof. Luciano Gualberto, Trav. 3, 158, 05508-900 São Paulo, SP, Brasil \\ ${ }^{3}$ Institute of Zoophysiology, Hohenheim University, Paracelsusstr. 91, 70599 Stuttgart, Germany \\ Manuscript received on February 28, 2008; accepted for publication on June 21, 2008, \\ presented by ALEXANDER W.A. KELLNER
}

\begin{abstract}
The isolated chick retina provides an in vitro tissue model, in which two protocols were developed to verify the efficacy of a peptide in the excitability control of the central gray matter. In the first, extra-cellular potassium homeostasis is challenged at long intervals and in the second, a wave is trapped in a ring of tissue causing the system to be under self-sustained challenge. Within the neuropil, the extra-cellular potassium transient observed in the first protocol was affected from the initial rising phase to the final concentration at the end of the five-minute pulse. There was no change in the concomitants of excitation waves elicited by the extra-cellular rise of potassium. However, there was an increase on the elicited waves latency and/or a rise in the threshold potassium concentration for these waves to appear. In the second protocol, the wave concomitants and the propagation velocity were affected by the peptide. The results suggest a synergetic action of the peptide on glial and synaptic membranes: by accelerating the glial Na/KATPase and changing the kinetics of the glial potassium channels, with glia tending to accumulate $\mathrm{KCl}$. At the same time, there is an increase in potassium currents through nerve terminals.
\end{abstract}

Key words: extra-cellular potassium, migraine, neuronal-glial dynamics, somatostatin, spread depression.

\section{INTRODUCTION}

The isolated chicken retina provides an experimental model that have been studied for more than 40 years and basic research on the spreading excitation phenomenon is well developed (Martins-Ferreira and Oliveira e Castro 1966, Martins-Ferreira and Do Carmo 1987, Fernandes de Lima and Hanke 1997). In this paper, we present two protocols designed to monitor efficacy properties of a peptide against G-protein coupled receptors in intact tissue. The neuropeptide used was Somatostatin (SS), a family of homologous integral membrane proteins (receptors SST 1 to 5). The receptors regulate

Correspondence to: José R.C. Piqueira

E-mail: piqueira@lac.usp.br protein phosphorylation, control second messenger production and regulate membrane potential partly through voltage and $\mathrm{Ca}$-dependent potassium channels. Structurally, SS receptors belong to the superfamily of Gprotein coupled receptors (Moller et al. 2003). All the five receptors have been reported in vertebrate retinas, in neuronal, glial and endothelial cells (Thermos 2003). The SST 2 receptor acts through the NO/c-GMP pathway in neuronal and glial cell lines in the retina (Vasilaki et al. 2002, 2004, Mastrodimou et al. 2006). The protective effects of SS against excitotoxicity appear to be mediated via this receptor (Catalani et al. 2007).

The effects of c-GMP either through NO donors or membrane permeable c-GMP derivatives on retinal 
waves have been recorded in this experimental model (Ulmer et al. 1995, Dahlem and Hanke 2005). Thus, one could predict the effects on the electrophysiological potassium wave concomitants (Do Carmo and MartinsFerreira 1984) recorded in the experiments reported in this paper. The expected results were: lower amplitude of the wave concomitants, acceleration of equilibrium within the neuropil of exogenous potassium pulses, rise in threshold for wave elicitation and decrease in propagation velocity of excitation waves (retinal spreading depression waves).

The in vitro chick retina provides an ideal tissue model to observe excitation waves (Fernandes de Lima and Hanke 1997), and the spread of excitation waves are a good model to observe neuronal-glial interactions. Furthermore, the central gray matter of the retina has the widest dynamic range of operation (six log units of input energy from dark adapted to full day light) and thus its network must have very fine control of excitability, in order to maintain the output under light and in the dark.

Somatostatinergic pharmacology is under investigation for a wide range of therapeutic applications ranging from anti-proliferating agent in cancer and diabetic retinopathy, to analgesic and antiepileptic action (Thermos 2003, Binaschi et al. 2003) as well as modulatory action in cognitive syndromes such as Alzeimer's dementia, and as a cognition enhancing agent (Epelbaum 1986, Pittaluga et al. 2001, Kumar 2005).

The two protocols presented here were made such that the central nervous system is observed at very different states. In the first, exogenous potassium pulses are applied in a system at rest, or at least with large time intervals between challenges to the ionic homeostasis. On the other hand, in the second protocol, the system is maintained in a state of permanent challenge by trapping an excitation wave in a circle of tissue (MartinsFerreira et al. 1975). The effect of the peptide is observed in the extra-cellular potassium and potential drop transients that accompanies the wave propagation, as well as in the propagation velocity within a cycle.

The results of both protocols are interpreted in the context of the conceptual framework derived from the non-linear thermodynamics that describes waves in excitable systems (Nicolis and Prigogine 1989).
It must be emphasized that the aim of these experiments is to obtain qualitative conclusions about the modulation of oscillations and electrochemical waves and their interactions at the multicelular level of the CNS (Central Nervous System). Consequently, the data are analyzed without statistical techniques, as the systems are considered to respond in a robust way to the stimulus presented (Dahlem and Hanke 2005, Siegel 1996, Epelbaum, 1986).

\section{MATERIALS AND METHODS}

The methods used here are described by (Do Carmo and Martins-Ferreira 1984, Martins-Ferreira et al. 1975). The chosen SS concentration was in the micro-molar order of magnitude, three orders of magnitude larger than the used with isolated receptors (Martins-Ferreira and Oliveira e Castro 1966, Martins-Ferreira and Do Carmo 1987, Fernandes de Lima and Hanke 1997).

\section{AgEnTs}

The Somatostatin 14 and 28 were purchased from Sigma, St. Louis, MO, USA. The ion-exchanger resine used was the Corning 477317 for K.

\section{Animals and Slice Preparation}

Young chicks with ages from 10 to 15 days were killed by decapitation and the enucleating processes of the eyecups were performed immediately. The vitreous humors were removed and the eyes were cut in strips of about $4 \times 10 \mathrm{~mm}$, which were immersed in Ringer's solution maintained at 30 degrees Celsius.

Only tissue experiments were done, and they are in agreement with all federal regulations of the involved authors' countries.

\section{RETINA RINGER's SOLUTION}

$\mathrm{NaCl} 100 \mathrm{mM}$; KCl 6 mM; $\mathrm{Na} \mathrm{H}_{2} \mathrm{PO}_{4} 1 \mathrm{mM} ; \mathrm{NaHCO}_{3}$ $30 \mathrm{mM} ; \mathrm{MgSO}_{4} 1 \mathrm{mM} ; \mathrm{CaCl}_{2} 1 \mathrm{mM}$; Tris $10 \mathrm{mM}$ and Glucose $30 \mathrm{mM}$. The $\mathrm{pH}$ of the solution was adjusted to 7.4 .

\section{Electrodes And Recording System}

Double barred ion-selective electrodes were manufactured and the potential sensing probe filled with $150 \mathrm{mM}$ 
$\mathrm{NaCl}$. The silanized ion-sensitive tip (filled with Corning 477317) was backfilled with $150 \mathrm{mM} \mathrm{KCl}$. All potentials recorded within the retina were measured against a grounded silver/silver chloride/agar/Ringer's bridge electrode. The electrodes tips had a diameter between 10 and 20 microns. At the beginning and at the end of the experiments, the electrodes response was calibrated using Ringer's solutions in which the potassium concentration was raised to $10,15,30$ and $60 \mathrm{mEq} / \mathrm{l}$ substituting for equal amounts of $\mathrm{NaCl}$ taken from the Ringer in order to maintain osmolarity. The extra-cellular potential and potassium activity sensing probes were mounted in a micro-drive and the output connected to a two-channel electrometer (WPI-FD-223). The signals were displayed in a Grass paper recording and saved in a magnetic tape for further processing.

Protocol I - Exogenous Administration OF High PotAssium Ringer's SOLUTIONS

According to the description presented in (Do Carmo and Martins-Ferreira 1984), the slices of retina were separated from the sclera preserving the pigment epithelium as much as possible and transferred to an experimental chamber where they were positioned with the vitreous side up. The chamber had a volume of $0.2 \mathrm{ml}$ and it was perfused with Ringer at a rate of $0.6 \mathrm{ml} / \mathrm{min}$. It was assured a uniform laminar flow with no mechanical disturbance. A bypass system coupled to the main superfusing circuit was used to introduce the high potassium pulses through the opening of valves, so that no mechanical disturbance was associated with the change in potassium as is the case with pressure injection techniques. The temperature was maintained at $30^{\circ} \mathrm{C}$. After positioning the electrode at the centre of the slice and within the inner plexiform layer, a control wave was elicited mechanically with a gentle touch with a tungsten needle (tip diameter less than 100 microns). The stimulus was delivered closed to the exit of the perfusion solution such that the wave propagated against the flow. The presence of the wave was verified observing the intrinsic optical signal associated with it. In Figure 1, the extra-cellular potassium concentration and potential associated with the retinal spreading depression wave recorded at the inner plexiform layer is shown.

The sharp profile of these concomitant waves across the retina makes possible to recognize the electrode position (Do Carmo and Martins-Ferreira 1984). After 30 minutes rest, pulses of high potassium solutions were introduced in the perfusion system. Concentrations of 10,12 and $15 \mathrm{mEq} / \mathrm{l}$ were used. Recordings began 10 minutes before the pulse and continued until 5 minutes after the extra-cellular level came back to baseline level. One-hour interval was used between pulses of increasing concentrations. A second series of pulses was applied by adding Somatostatin to the high potassium pulses at concentrations of 1 and 4 micro-mol in different slices.

\section{Protocol II - The Circling Wave Preparation}

The method to obtain circling waves has already been published in detail (Martins-Ferreira et al. 1975, Fernandes de Lima et al. 1993, Fernandes de Lima and Hanke 1996). In brief, after removing the vitreous, a circular cut was made in the eyecup forming a ring of tissue. The eyecup was positioned in a perfusion chamber with $5 \mathrm{ml}$ volume capacity. The rate of perfusion was $1.2 \mathrm{ml} / \mathrm{min}$. In the narrow part of the ring, a wave was elicited by a gentle touch destroying one of the wave fronts by spraying a Ringer solution with a magnesium sulfate concentration of $4 \mathrm{mM}$ over it, by using a syringe and flexible needle. The other front was let to propagate and the flow in the system transiently increased to $12 \mathrm{ml} / \mathrm{min}$ (about 20 seconds). With a wave trapped in the ring of tissue, the electrode was positioned in the inner plexiform layer. When the propagation velocity was stabilized, usually after 10 to 15 cycles, the perfusion solution was changed to a Ringer containing $\mathrm{SS}$ at a $4 \mu \mathrm{M}$ concentration for 30 minutes. If the circling continued, a second exogenous administration of SS was applied.

\section{RESULTS}

\section{PROTOCOL I}

In Figures 2 and 3 we show the extra-cellular potassium and potential dynamics within the inner plexiform layer in response to exogenous administration of high potassium solutions in the absence and presence of SS. A total of 8 slices were used in the experiments. In five slices SS14 was utilized and in 3 SS 28 . The results were very 

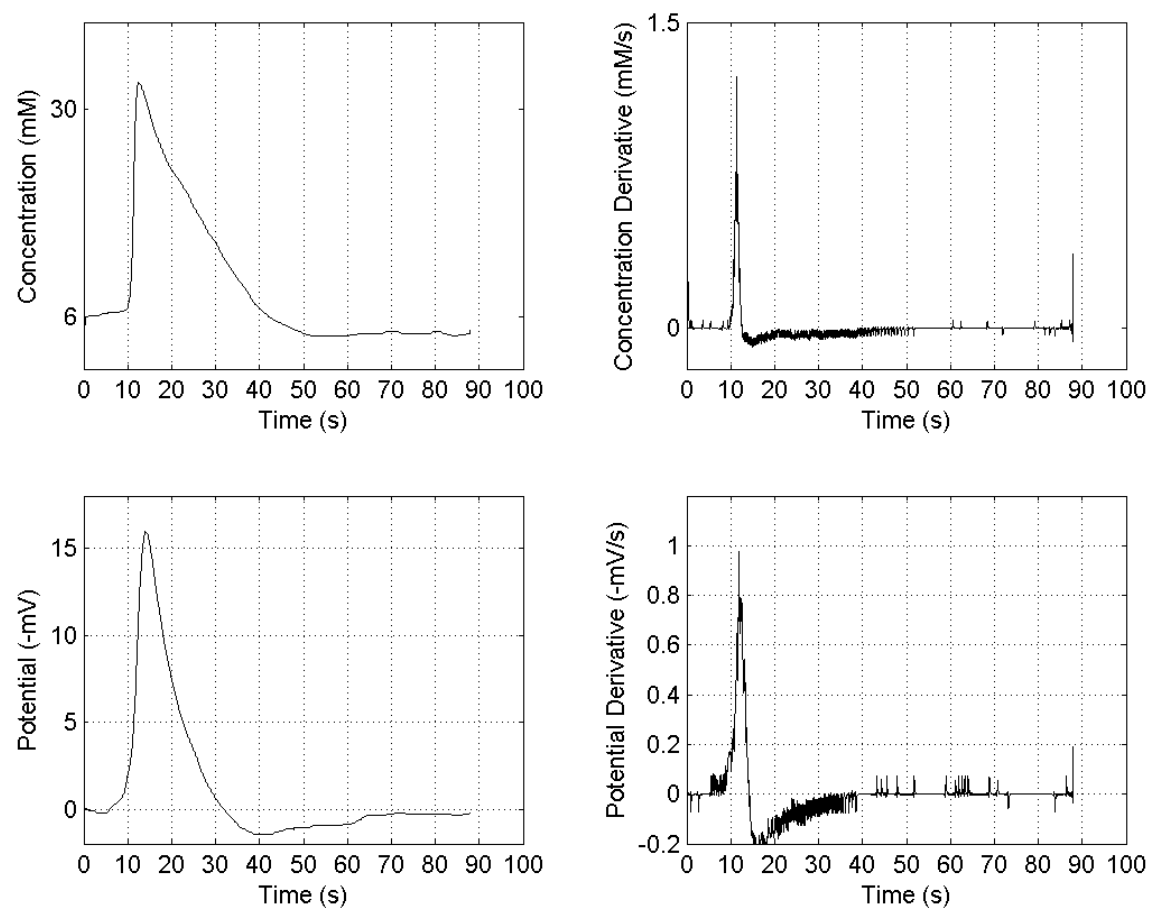

Fig. 1 - Typical record of electrophysiological wave concomitants at the inner plexiform layer of chick retina. Upper row: Extra-cellular potassium activity and its derivative. Lower row: Extra-cellular potential and its derivative.

similar with either peptide and thus are presented only as SS.

The laminar flow of solution implied a constant rate of rise of potassium in the bulk solution, proportional to the added $\mathrm{K}$ concentration in the Ringer. The bulk solution reached equilibrium within forty seconds of perfusion change (not shown), but the tissue response was slower and more complex.

The tissue response can be divided into four phases, the rising phase with two slopes, the non-linear "mass active" phase with or without a full wave, and the falling off phase. In Figure $2 \mathrm{C}$ the details of the rising phase of the potassium within the inner plexiform layer are shown. An accelerated one follows a slow linear rise followed by a non-linear increase reaching a peak that usually was above the exogenous applied potassium concentration. This dome shaped "active" response produced potential drops of 200 to $300 \mu \mathrm{V}$. The potential drop is shown in the trace bellow the potassium record.

In Figure 2A, the two traces show the tissue response to a pulse of $10 \mathrm{mEq} / \mathrm{l}$ of potassium. After the peak of the dome response $(11 \mathrm{mEq} / \mathrm{l})$, the extra-cellular potassium activity falls to $9 \mathrm{mEq} / \mathrm{l}$ and slowly rises up to the abrupt explosive growth of a spreading depression wave. In Figure 2B the two traces show the tissue response in the presence of SS $(4 \mu \mathrm{M})$. There was one hour interval between the recordings shown in A and B. One can notice that the faster rising phase and the potassium decrease in the sequel imply a long latency for the appearing wave.

In Figures 3A-E, the sequence of pulses of another experiment is shown. In this experiment, the interval between pulses was also of one hour. The concentration of SS added to the Ringer was of $1 \mu \mathrm{M}$. The extra-cellular potassium peaks at the "active" dome were: $10,5 \mathrm{mEq} / 1$ for the $10 \mathrm{mEq} / 1 \mathrm{~K}$ pulse, $15 \mathrm{mEq} / 1$ for the $12 \mathrm{mEq} / 1$ and $18 \mathrm{mEq} / 1$ for the $15 \mathrm{mEq} / 1$. These values were measured for the potassium challenges in the absence of SS. In the presence of $1 \mu \mathrm{M}$ of SS, the values were $14 \mathrm{mEq} / 1$ for the $12 \mathrm{mEq} / \mathrm{l}$ pulse and also 14 for the $15 \mathrm{mEq} / 1$ pulse. At the end of the five-minute pulse, the values of the potassium activity within the IPL were: $10 \mathrm{mEq} / 1$ for the $10 \mathrm{mEq} / 1 \mathrm{pulse} ; 12 \mathrm{mEq} / 1$ for the 12 and $15 \mathrm{mEq} / 1$ for the $15 \mathrm{mEq} / \mathrm{l}$ pulse in the absence of exogenous SS. 
A

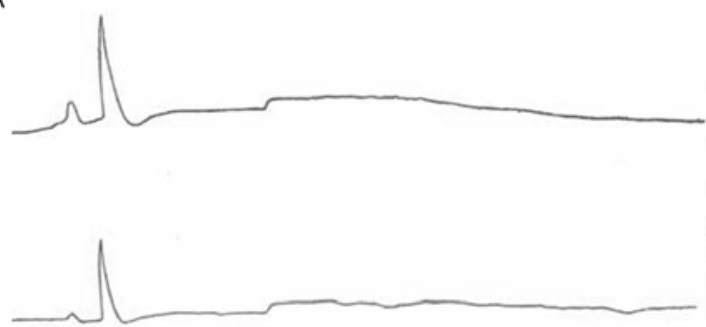

C

B
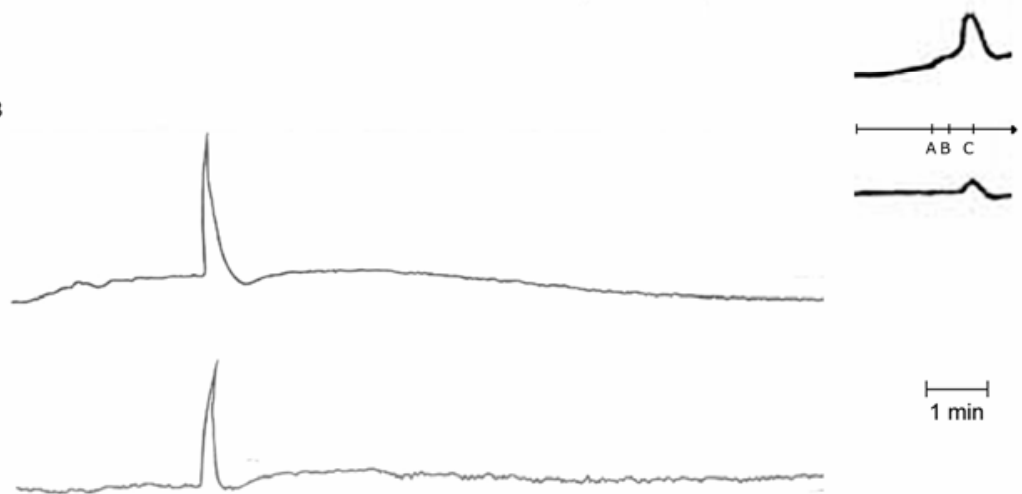

Fig. 2 - A - Upper row: extra-cellular potassium concentration versus time, lower row: simultaneous extra-cellular potential (mV) versus time. The pulse of potassium concentration is from 6 to $10 \mathrm{mEq} / \mathrm{l}$. B - Same slice one hour later. C - Detail of the initial response shown in A. The labels A, B and C in C picture show three phases of initial growth, two linear and the last non-linear "active" response.

A

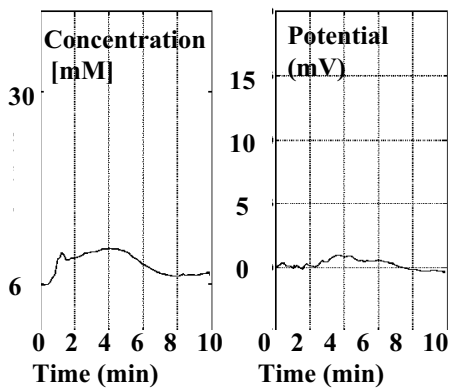

B

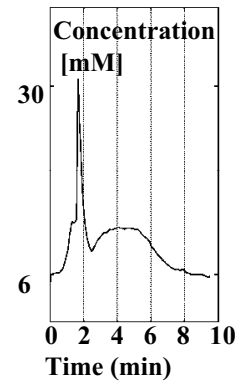

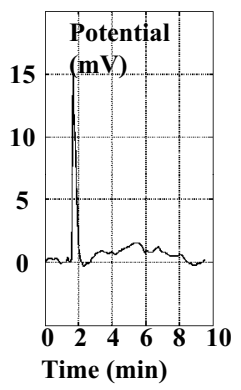

Time (min)
C

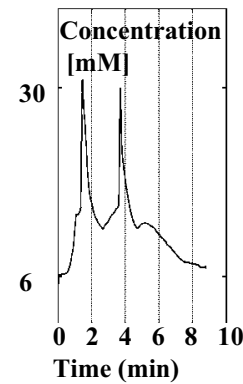

D

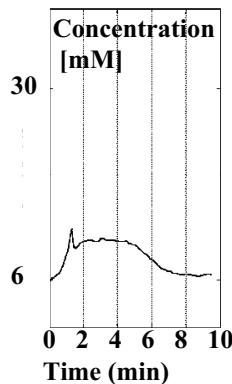

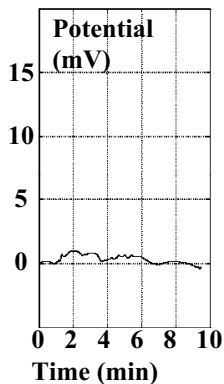

$\mathbf{E}$

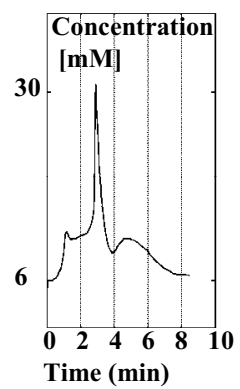

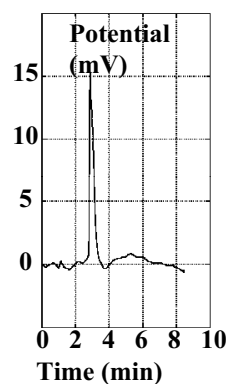

Fig. $3-\mathrm{A}, \mathrm{B}$ and $\mathrm{C}$ are the response to exogenous potassium pulses of another slice. The interval between pulses was one hour. The concentrations used were $\mathrm{A}=10 \mathrm{mEq} / \mathrm{l}, \mathrm{B}=12 \mathrm{mEq} / 1$ and $\mathrm{C}=15 \mathrm{mEq} / 1$. In $\mathrm{D}=12 \mathrm{mEq} / 1$ and $\mathrm{E}=\mathrm{mEq} / 1, \mathrm{SS}$ at $1 \mu \mathrm{M}$ was added to the pulse solution. 
In the presence of the peptide, the values were $11 \mathrm{mEq} / \mathrm{l}$ for the $12 \mathrm{mEq} / 1 \mathrm{pulse}$ and $10.5 \mathrm{mEq} / 1$ for the $15 \mathrm{meq} / 1$ pulse. The recovery phase was always much slower than the rising phase, and it took between 5 to 6 minutes to return to the baseline values.

Finally, the presence of SS had a marked influence in the exogenous potassium pulses ability of eliciting full fledge propagating excitation waves in the retinas. As can be seen in Figures 2 and 3, in the presence of SS waves, the propagation of the excitation was elicited with longer latencies. On the other hand, the internal wave dynamics, i.e., the peak extra-cellular potassium, the potential drop values and the explosive rate of growth of both variables were not affected by the peptide. In Figures 2 and 3 the qualitative changes in the tissue response observed in the presence of SS are shown: there was either an increase in the threshold level for the exogenous applied potassium to elicit waves, or the latency for the wave was increased. In Figure 3 the threshold was increased from 12 to $15 \mathrm{mEq} / \mathrm{l}$. The response to the $15 \mathrm{mEq} / \mathrm{l}$ pulse, instead of two, presented only one wave. Also the levels of extra-cellular potassium in the tissue at the end of the pulse (5 minutes) were lower in the presence of SS.

\section{PROTOCOL II}

The circling wave experiments were performed in 6 eyecups. The SS concentration used was $4 \mu \mathrm{M}$ in all experiments. Figures 4 and 5 summarize the results of a typical experiment. In Figure 4 the mean propagation velocity is plotted against the wave cycle number. The recording electrode was positioned very close to the border of the inner circular cut. The length of this circle was $20 \mathrm{~mm}$. Dividing $20 \mathrm{~mm}$ by the period in minutes between one wave and next, one obtains the propagating velocity for that period. A total of 45 waves were recorded in this experiment, close to 4 hours recording time. Twenty-two waves were recorded before the first exogenous application of SS to the system. This first application happened after a long period of steady state behavior of propagation velocity and extra-cellular potassium and potential drop dynamics. In Figure 5A-E the shape of successive electrochemical wave concomitants is displayed.
The propagation velocity before SS administration was $(\mathrm{n}=22) 4.22 \mathrm{~mm} / \mathrm{min} \pm 0.04$. The minimum value after 30 minutes of SS was $3.7 \mathrm{~mm} / \mathrm{min}$, a reduction of $11 \%$. Washing out the peptide produced partial recovery of the propagation velocity $(n=8) 4.02 \pm 0.04$.

A second application of the peptide (20 minutes) again reduced the velocity to a minimum of $3.58 \mathrm{~mm} /$ min and then the circling stopped at about 30 minutes after the removal of SS application. Under the influence of the peptide the propagation velocity was $(\mathrm{n}=14)$ $3,86 \mathrm{~mm} / \mathrm{min} \pm 0.21$.

In Figure 5A-E, we show the temporal evolution of the extra-cellular potassium and extra-cellular potential drop concomitant to the wave passage around the electrodes.

The recordings shown in Figure 5 correspond to the waves marked in Figure 4 by dark bars under the plot. The three waves in $\mathbf{A}$ and $\mathbf{B}$ were recorded before the application of SS. The waves in $\mathbf{C}$ were recorded at the beginning of the 30 minutes application and in $\mathbf{D}$ at the end of it.

The waves in $\mathbf{A}$ and $\mathbf{B}$ show the potassium peaks fluctuating near $30 \mathrm{mEq} / \mathrm{l}$ and the potential drop around $20 \mathrm{mV}$. When SS was added to the Ringer (traces $\mathbf{C}$ ), the peak potassium at the beginning was not affected; by contrast, the potential drop was decreased by $5 \mathrm{mV}$. At the end of the pulse (traces D), the peak potassium was slightly increased compared to the control values as well as the potassium wave duration. The extra-cellular potential drop fell to $12 \mathrm{mV}$ (a reduction of $40 \%$ in amplitude). SS was washed off after the second wave in $\mathbf{D}$ and there was an immediate recovery of the propagation velocity and amplitude of the potential drop. A second application of SS depressed all the wave concomitants. On SS removal, there was partial recovery of the peak amplitudes whereas the under shoot of the potassium was even more prolonged (trace $\mathbf{E}$ ).

In the circling wave protocol the SS effects were to slow down propagation velocity, to depress the extracellular potential drop and to increase the duration of the extra-cellular potassium transient, particularly the under shoot of the extra-cellular potassium activity within the neuropil. 


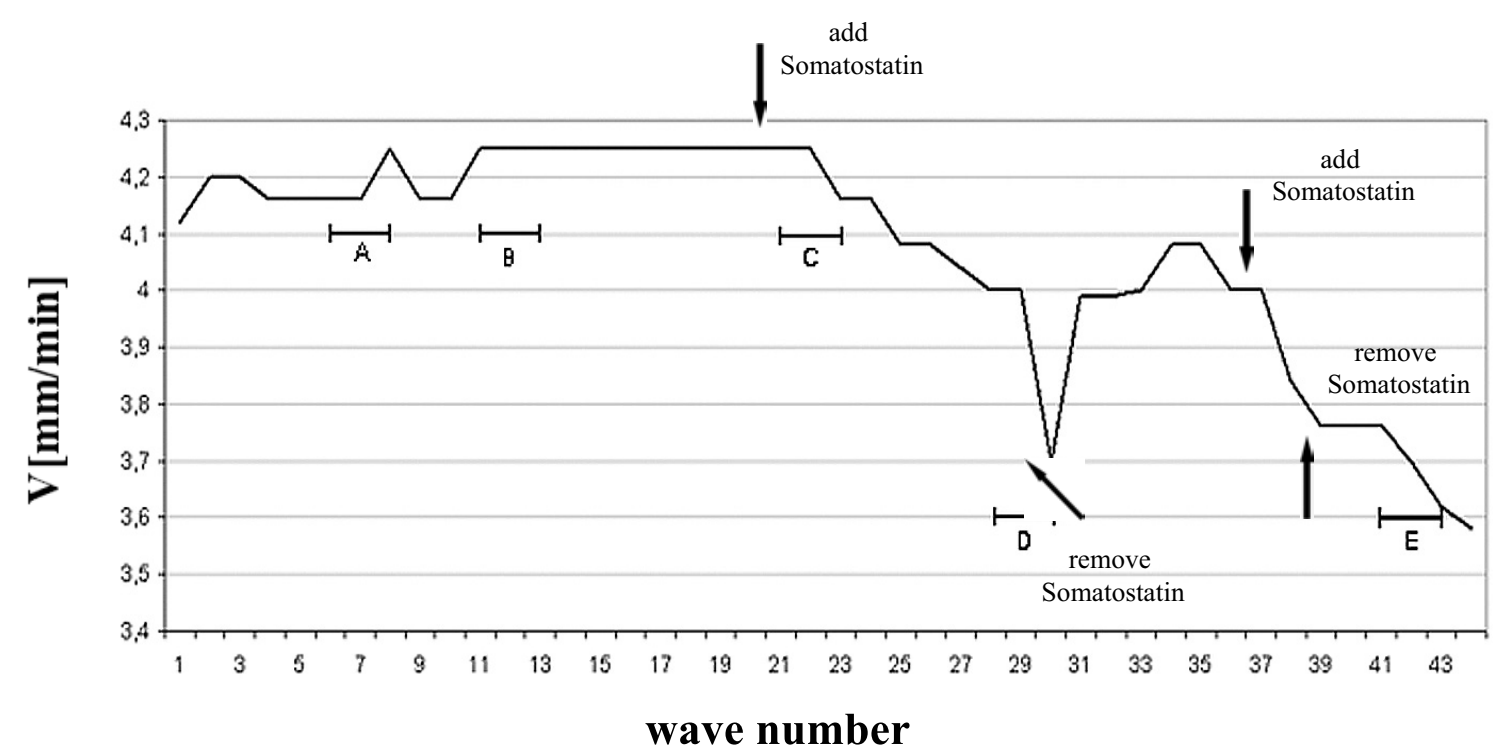

Fig. 4 - Wave propagation velocity $(\mathrm{mm} / \mathrm{min})$ through a circle of $20 \mathrm{~mm}$ length versus the wave number. The intervals A to E show the waves that have the electrophysiological concomitants shown in Figure 5.

A

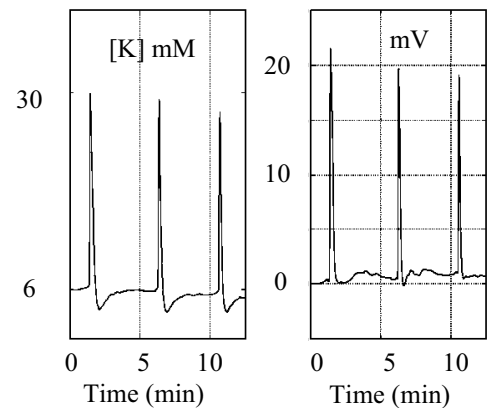

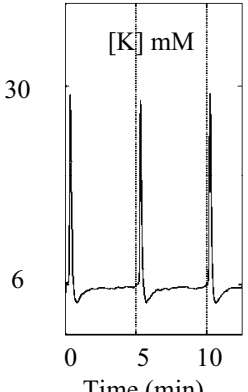

$\mathrm{D}$

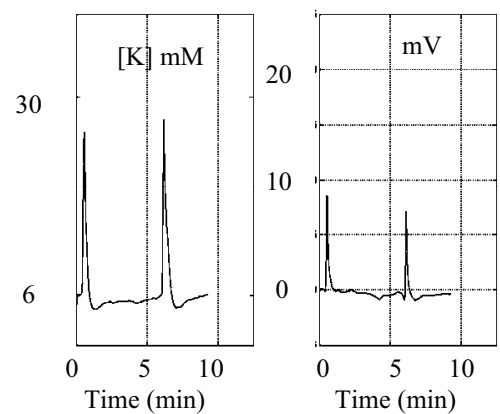

B
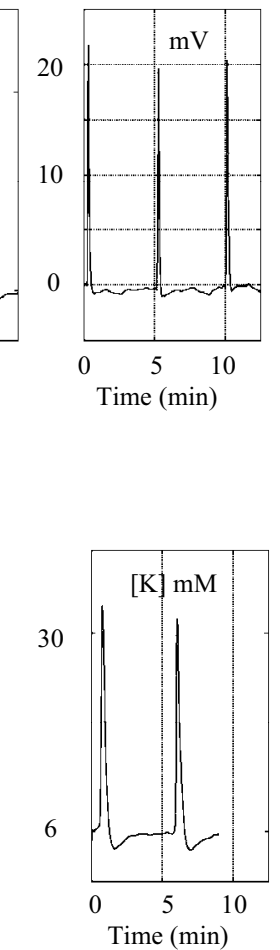

C
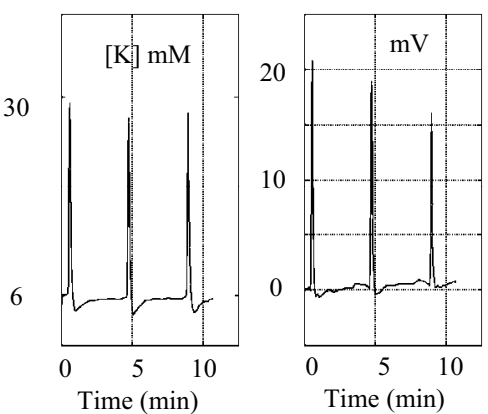

E

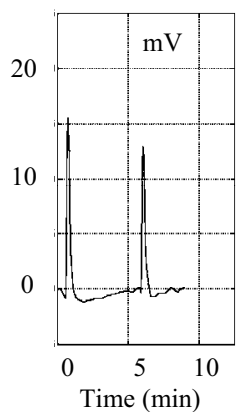

Fig. 5 - Wave propagation corresponding to the intervals of Figure 4. 


\section{DISCUSSION}

The SS INFLUENCE IN THE Global Response OF THE Central Gray Matter

In the presence of SS, the threshold extra-cellular potassium concentration needed to elicit excitation waves was increased and the latency of elicited waves was prolonged. SS also affected the propagation velocity of circling waves slowing down the propagation. A second observed change in circling experiments was the decrease in brightness of the intrinsic optical signals that are concomitant with retinal spreading depression waves - the IOS of RSDs (Fernandes de Lima and Hanke 1997). These qualitative changes suggest synergy of effects in glial and neuronal membranes in the direction of a dampening in the tissue excitability. These results were expected and are in agreement with the previous findings with NO donors and the membrane permeable c-GMP derivatives (Ulmer et al. 1995, Dahlem and Hanke 2005). For example, the optical profile recorded in spatial line projection shows acceleration of recovery, a signal of $\mathrm{Na} /$ KATPase acceleration (Ulmer et al. 1995) an effect also observed with increasing the temperature (Weimer and Hanke 2005). The overall mean effect on the wave optical signals after 2 hours perfusion with NO donors was depression of amplitude of both peaks of the temporal profile of the intrinsic optical signal (Dahlem and Hanke 2005) suggesting both potassium channels and metabolic rate effects. We just measured the close association of the glial $\mathrm{Na} / \mathrm{KATPase}$ pumping rate and the temporal profile of retinal waves.

The initial effect on the rising rate in the neuropil case, with exogenous application of potassium, can only be explained by glial membrane effects, because between the neuropil and the vitreous there is only a base membrane secreted by glia and the end feet of the Muller cells. The end feet membrane expresses both potassium channels and the $\mathrm{Na} / \mathrm{K}$ ATPase. During long pulses application of the SS in the second protocol, the under shoot of potassium is prolonged from 1.5 to $5 \mathrm{~min}$. The best explanation for this finding is that glia cells are accumulating $\mathrm{K}$ by accelerating the pump and changing the kinetics of their $\mathrm{K}$ channels.

For this interpretation we use knowledge from previous experiments with patch-clamping glial and neuronal $\mathrm{K}$ channels both in situ during the wave passage and with isolated cells (Hanke et al. 1993, 1997), the effect of Barium on circling waves (Fernandes de Lima et al. 1993), and intracellular recordings on glia upon barium application (Ballany et al. 1987, Chesler and Kraig 1989), i.e., glia hyperpolarizes and the membrane resistance rises. Also we use the findings of Reichenbach et al. on the Muller cells $\mathrm{Na} / \mathrm{KATPase}$ behavior (Reichenbach et al. 1992), i.e., potential is maximal at extra-cellular potassium concentrations of 10 to $15 \mathrm{mM}$. Besides, the pump will transport potassium into the cell even with low intracellular sodium. For example, by elevating potassium in the bath to $15 \mathrm{mEq} / \mathrm{l}$, the optical wave profile will show a depressed second peak. The exogenous potassium accelerates the pump rate to maximum, such that the breakdown of electrochemical gradients at the wavefront is not able to further accelerate it. As a consequence, the glycolysis is not increased in glia, it is at maximum rate before the wave. The second peak of the optical profile follows closely the $\mathrm{pH}$ shift in the extra-cellular space and lactate production by glia (Ferreira-Filho and Martins-Ferreira 1992, Hansen and Quistorff 1993).

Throughout the years, it was observed that the power of modulation of the propagation velocity is a good predictor for the efficacy of antimigraine, antiepileptic and protection from excitotoxicity (Ulmer et al. 1995, Wiedemann et al. 1996, Wiedemann and Hanke 1997). In dissipative structure context, this effect could be related to the global coupling within the system. The artificial model of bioelectrochemical waves developed by Wussling (Wussling et al. 1999, 2001) in which sarcoplasmic membrane vesicles and mitochondria are embedded in agarose, showed that the addition of mitocondria to the vesicle system promoted the doubling of propagation velocity of calcium waves and the smoothing of the wavefront shape. We also observed the wavefront breakdown with agents that slow propagation in the retina, propanolol and Sumitriptan are examples of such compounds. The present results suggest that the peptide SS synergic action uncouples the elements in the tissue, i.e., the glial and synaptic membranes interacting through the extra-cellular matrix.

\section{The SS EFFECts on the EXCitation Wave CONCOMITANTS}

The extra-cellular potassium and potential transients dynamics in each wave follow a sequence of dominant 
phases: the abrupt rise in potassium and simultaneous drop in potential, followed by a much slower recovery that have a potassium and potential under shoot. The time derivatives of both transients have a dominant peak that occurs at the same time for the two variables (Fig. 1). At the concentrations used (1 and $4 \mu \mathrm{M})$, Somatostatin did not alter the peak of the time derivative of the extra-cellular potassium and potential transients in both protocols. On the other hand, the peak of the extra-cellular potassium and potential were not affected in the first protocol (Figs. 2 and 3) whereas both peaks were depressed in the second protocol (Fig. 5), with the extra-cellular potential drop more affected than the potassium. The c-GMP build up with the longer pulses can explain the difference of short term and long-term effects of the peptide. In the circling experiments, the potassium transient duration was increased as well as the potassium under shoot (Fig. 5D). This difference is a direct verification about the experimental context influence in the whole tissue response to a single pharmacological agent. A change in the dynamics of the neuronal/glial interactions can change the pharmacological result.

This type of verification shows the importance of tissue models in pre-clinical research and their role between the high throughput in vitro receptor affinity measurements and the whole animal response used in toxicology.

\section{CONCLUSIONS}

There is enough knowledge about excitation waves in in vitro chicken retina that some results of pharmacological manipulations can be predicted. In the experiments shown in this paper, the predicted results could be seen by using two different protocols concerning to the same model. We assumed that since the protective effects of SS against ischemia were related to SST2 receptor and c-GMP, then the measurable effects of SS on excitation waves had to be related to c-GMP effects. Potassium ion regulation is one key feature of neuronal-glial interaction, and the mechanisms subjacent to this control are present in physiological and pathological situations. The spreading depression wave in the retina is a sensitive, highly reproducible and multiparameter event that can be very useful in the pre-clinical drug development process.

\section{RESUMO}

Retinas de pinto isoladas proporcionam um modelo de tecidos in vitro, para o qual dois protocolos foram desenvolvidos para verificar a eficácia de um peptídeo no controle da excitabilidade da matéria cinzenta central. No primeiro, a homeostase do potássio extra-celular é desafiada por intervalos longos (1 hora) e no segundo, uma onda é capturada em um anel de tecido, de tal maneira que o sistema permaneça em estado de desafio auto-sustentado. Dentro da neuropil, o transiente de potássio extra-celular observado no primeiro protocolo foi afetado da fase de início de aumento à concentração final, ao final do pulso de cinco minutos. Não há mudanças nos parâmetros concomitantes das ondas de excitação geradas pelo aumento do potássio extra-celular. Entretanto, houve um aumento da latência das ondas geradas e/ou um aumento no nível de concentração de potássio necessário para gerar a onda. No segundo protocolo, os parâmetros concomitantes da onda e sua velocidade de propagação foram afetados pelo peptídeo. Os resultados sugerem uma ação sinergética do peptídeo nas membranas gliais e sinápticas: acelerando o Na/KATPase glial e mudando a cinética dos canais de potássio gliais, com a glia tendendo a acumular $\mathrm{KCl}$. Nesse período, não há aumento nas correntes de potássio nas terminações nervosas.

Palavras-chave: potássio extra-celular, enxaqueca, dinâmica neuronal, dinâmica glial, somatostatina, depressão alastrante.

\section{REFERENCES}

Ballany KP, Grafe P AND BRUgGencate G. 1987. Ion activities and potassium uptake mechanisms of glial cells in guinea pig olphactory cortex slices. J Physiol (London) 382: $159-174$

Binaschi A, Bregola G and Simonato M. 2003. On the role of somatostatin in seizure control: clues from the hippocampus. Rev Neurosci 14: 285-301.

Catalani E, Cervia D, Martini D, Bagnoli P, Simonatti E, Timperio AM And Casini G. 2007. Changes in neuronal response to ischemia in retinas with genetic alteration of somatostatin receptor expression. Eur J Neurosci 25: 1447-1459.

Chesler M AND Kraig RP. 1989. Intracellular pH transients of mammalian astrocytes. J Neurosci 9: 20112019.

DAHLEM Y AND HANKE W. 2005. Intrinsic optical signal of retinal spreading depression: second phase depends on energy metabolism and nitric oxide. Brain Res 1049: 15-24. 
Do CARMo R AND Martins-FerReira H. 1984. Spreading depression of Leão probed with ion-selective microelectrodes. An Acad Bras Cienc 56: 401-421.

EPELBAUM J. 1986. Somatostatin in central nervous system: physiology and pathological modifications. Prog Neurobiol 27: 63-100.

FERNANDES DE LIMA VM AND HANKE W. 1996. Observations of non-stationarities in extra-cellular potassium dynamics within the gray matter neuropil during self-sustained spreading depression. J Brain. Res 37: 505-518.

Fernandes de Lima VM and Hanke W. 1997. Excitation waves in central gray matter: the retinal spreading depression. Prog in Retin Eye Res 16: 657-690.

Fernandes de Lima VM, Scheller D, Tegtmeyer F, HANKe W AND Schlue WR. 1993. Self-sustained spreading depression in the chicken retina and short term neuronal glial interactions within the grey matter neuropil. Brain Res 614: 45-51.

FERreira Filho CR AND MARTINS-Ferreira H. 1992. Interstitial fluid $\mathrm{pH}$ and its changes during spreading depression in isolated chicken retina. in Spreading Depression. DoCarmo R (Ed.), Springer-Verlag Berlin, Heidelberg, NY, p. 75-88.

Hanke W, Fernandes de Lima VM and Schlue WR. 1993. Patch-clamp experiments in the intact retina during spreading depression. In: LEHMENKUELER A, GROTEMEYER KH AND TEgTMEYER F (Eds.), Migraine: basic mechanisms and treatment. Urban \& Schwarzenberg, Munich, p. 573-582.

Hanke W, Mezler M, Brand S, Ladewig T and FerNANDES DE LIMA VM. 1997. Patch-clamp experiments at isolated cells and in intact tissue of the chicken retina correlated to potassium channels and the retinal spreading depression. Electrochim Acta 42: 3231-3240.

HANSEN AJ AND QUISTORFF B. 1993. Glucose metabolism in experimental spreading depression. In: MIGRAINE: BASIC MECHANISMS AND TREATMENT. LEHMENKUEller A, GRotemeyer KH AND Tegtmeyer F (Eds.), Urban-Swarzenberg, Munich, p. 367-378.

KUMAR U. 2005. Expression of somatostatin receptors subtypes (STR1-5) in Alzheimers disease brain: an immunohistochemical analysis. Neurosci 134: 525-538.

MARTINS-FERreira H AND Do CARMo RJ. 1987. Retinal spreading depression and the extra-cellular millieu. Can J Physiol Pharmachol 65: 1092-1110.

MARTINS-FERREIRA H AND Oliveira E CASTRo G. 1966. Light scattering changes accompanying spreading depression in isolated chicken retina. J Neurophysiol 29: 715726.
Martins-Ferreira H, Oliveira e CAstro G AND STRUCHINER CJ. 1975. Circling spreading depression in isolated chicken retina. J Neurophysiol 37: 773-784.

Mastrodimou N, Kiagiadaki F, Hodjarova M, EfTHIMIA K AND THERmos K. 2006. Somatostatin receptors (SST2) regulate cGMP production in rat retina. Regul peptides 133: 41-46.

Moller LN, Stidsen CE, Hartmann B and Holst JJ. 2003. Somatostatin receptors. Biochem Biophys Acta 1616: 1-84.

NiCOLIS G AND PRIGOGINE Y. 1989. Exploring complexity: An introduction. W.H. Freeman Company, NY, 313 p.

Pittaluga A, Feligioni M, Ghersi C, Gemignani A AND RAITERI M. 2001. Potentiation of NMDA receptor function through somatostatin release: a possible mechanism for the cognition-enhancing activity of GABAb receptor antagonists. Neuropharmachology 41: 301-310.

Reichenbach A, Henke A, Eberhardt W, Reichelt W AND DETTMER D. 1992. K ion regulation in retina. Can J Physiol Pharmachol, Supp 70: S239-S247.

SIEGEL G. 1996. Connective tissue: more than just a matrix for cells. In: COMPREHENSIVE Human Physiology. GREGER R AND WindHORST U (Eds.), Springer 1: 173228.

THERMos K. 2003. Functional mapping of somatostatin receptors in the retina: a review. Vis Res 43: 1805-1815.

Ulmer HJ, Fernandes de Lima VM and Hanke W. 1995. Effects of nitric oxide on retinal spreading depression. Brain Res 691: 239-242.

Vasilaki A, Mouratidou M, Shchulz S And TherMOS K. 2002. Somatostatin mediates nitric oxide production by activating SST2 receptors in rat retina. Neuropharmachology 43: 899-909.

VAsilaki A, Papadaki T, Notas G, Kolios G, MasTrodimou N, Hoyer D, TSilimbaris M, KourouMALIS E, PALLIKARIS I AND Thermos K. 2004. Effect of Somatostatin on nitric oxide production in human retinal pigment epithelium cell cultures. Invest Ophth Vis Sci 45: 1499-1506.

Weimer MS AND HANKE W. 2005. Correlation between the durations of refractory period and intrinsic optical signal of spreading depression during temperature variations. Exp Brain Res 161: 201-208.

WiEdEMANN M AND HANKE W. 1997. The chicken retina as a model for investigation of central nervous system lesions. Neurosci Lett 232: 99-102.

Wiedemann M, Fernandes de Lima VM and Hanke W. 1996. Effects of anti-migraine drugs on retinal spreading depression. Naunyn-Schiemederberg's Arch Pharmachol 353: 1-5. 
Wussling MHP, Kranich K, Landgraph G, Herrmann-Frank A, Wiedemann D, Gellerich FN AND PODHAISK H. 1999. Sarcoplasmic reticulum vesicles embedded in agarose gel exhibit propagating calcium waves. FEBS Lett 463: 103-109.
Wussling MHP, KRAnich K, DRYgalla V AND PODHASKI H. 2001. Calcium waves in agarose with cell organelles: implications of the velocity curvature relationship. Biophys J 80: 2658-2666. 